\title{
Spirometer Non-Invasive dengan Sensor Piezoelektrik untuk Deteksi Kesehatan Paru-Paru
}

\author{
KEMALASARI, PAULUS SUSETYO WARDANA, RATNA ADIL
}

Politeknik Elektronika Negeri Surabaya (PENS)

Email: kemala@pens.ac.id

\begin{abstract}
ABSTRAK
Polusi udara dapat mempengaruhi kesehatan paru-paru. Umumnya pengukuran fungsi paru menggunakan spirometer, dilakukan di rumah sakit dan membutuhkan waktu yang lama untuk mengetahui hasilnya. Untuk mengatasi masalah ini, dirancang Spirometer non-invasive yang portable dengan menggunakan sensor piezoelektrik yang diletakkan di dada. Perubahan tekanan yang diukur oleh sensor piezoelektrik adalah 10 - $80 \mathrm{mV}$, sehingga diperlukan rangkaian amplifier, filter, clamper, mikrokontroler AVR ATMega 32 sebagai pengolah data I/O dan LCD grafik untuk menampilkan hasil ukur serta SD card untuk menyimpan data. Alat ini mengukur kapasitas vital paru-paru, respirasi rate, dan jika hasil ukur kapasitas vital paru-paru kurang dari 80 \% dari nilai prediksi kapasitas paru-paru maka kondisi paru-paru dideteksi tidak sehat. Hasil dari pengujian menunjukkan bahwa persentase nilai keberhasilan alat adalah 95,70\%, hasil pengukuran dan deteksi kondisi paru-paru dapat langsung diketahui dari tampilan di LCD grafik, data hasil pengukuran bisa disimpan dan alat berukuran kecil sehingga portable, mudah digunakan oleh siapapun dan dimanapun dengan nyaman.
\end{abstract}

Kata kunci: Spirometer, Piezoelektrik, Mikrokontroler, Kapasitas Paru-Paru, LCD Grafik.

\begin{abstract}
Air pollution can be affected the health of the lungs. Generally the measurement of lungs function use a spirometry, performed in the hospital and takes a long time to know the results. To overcome this problem, a portable non-invasive Spirometry is designed using a piezoelectric sensors placed on the chest. The changes of pressure is measured by the piezoelectric sensor are 10 - $80 \mathrm{mV}$, so it needs a amplifier circuit, filter, clamper, ATMega 32 AVR microcontroller as I/O data processor and LCD graph to display result of measurement and SD card for save the data. This instrument measure lungs vital capacity, respiration rate, and if the measured of lungs vital capacity is less than $80 \%$ of the predicted of lung capacity, then the lung is detected unhealthy. The result of testing indicated that the percentage of success value of instrument is $95,70 \%$, the results of measurements and detection of lung conditions can be directly know from the view in LCD graphs, measurement data can be saved and size of instrument is small so portable, easy to use by anyone and anywhere with comfortably.
\end{abstract}

Keywords: Spirometry, Piezoelectric, Microcontroller, Lungs Capacity, LCD Graphic. 


\section{PENDAHULUAN}

Perubahan iklim yang ekstrim dan polusi udara yang disebabkan oleh debu, asap, gas buangan kendaraan dan industri dapat meningkatkan peluang terjangkit berbagai penyakit infeksi yang disebabkan oleh virus, terutama infeksi saluran pernapasan. Gangguan infeksi pernapasan yang terjadi secara serius dalam waktu yang lama dapat mempengaruhi kesehatan paru-paru. Jika pemeriksaan fungsi paru dilakukan secara cermat sejak dini, maka penyakit paru-paru dapat disembuhkan. Spirometer adalah sebuah alat yang berfungsi untuk mengukur seberapa banyak udara yang dapat dihirup (inspirasi) dan dihembuskan (ekspirasi) oleh seseorang dalam durasi tertentu sehingga hasil pengukurannya dapat memberi informasi tentang kesehatan paru-paru. Pengukuran fungsi paru-paru dengan spirometer, biasanya menggunakan klip penutup hidung untuk mencegah udara keluar melalui hidung dan pasien diminta untuk menarik napas sedalam mungkin dan kemudian dihembuskan secara maksimal (paksa) ke corong mesin spirometer yang sudah dilengkapi dengan sensor yang dapat mengukur volume udara yang dihirup dan dihembuskan serta kapasita paru-paru. Pada saat ini, pengukuran kondisi paru-paru harus dilakukan di rumah sakit dengan biaya yang tidak murah. Selain itu, hasil pengukuran kondisi paru-paru tidak bisa langsung diketahui karena pengukuran spirometer hanya memberi informasi tentang hasil pengukuran volume paru-paru saja.(Sini, 2015)

Moh. Fat'ak pernah merealisasikan spirometer dengan menggunakan sensor strain gauge MPX5100 yang diletakkan pada alat tiupdengan tujuan untuk menganalisa volume dan kapasitas paru-paru. Perubahan tegangan yang dihasilkan oleh sensor dikuatkan oleh rangkaian op-amp non-inverting, dan selanjutnya diintegrasikan ke PC dengan menggunakan mikrokontroler ATMega 16 sebagai pengolah data analog ke digital. Sinyal respirasi yang dihasilkan oleh alatmasih banyak mengandung noise sehingga sinyal respirasi masih harus diolah lagidengan filter FIR (Finite Impulse Response) untuk mengurangi noise, dan hasil pengukuran volume serta kapasitas paru-paru masih belum presisi dan memiliki prosentase error antara $10.95 \%$ sampai $38.8 \%$ jika dibandingkan dengan pengukuran menggunakan Biopac MP30.(Fat'ak, 2010)

Setiyo Ari Wibowo telah melakukan penelitian tentang perhitungan respirasi permenit dengan menggunakan sensor piezoelektrik. Hasil dari sensor piezoelektrik dapat digunakan untuk mendeteksi inspirasi dan ekspirasi sehingga dapat diketahui jumlah respirasi dan status pernapasannya. (Setiyo, 2010)

Aulia Rahma A pernah merealisasikan spirometer dengan menggunakan sensor piezoelektrik untuk menganalisa kesehatan paru-paru berdasarkan pengukuran volume dan kapasitas paru-paru. Sensor piezoelektrik yang digunakan sudah dapat bekerja dengan baik dan sudah dapat menganalisa kesehatan paru-paru. (Aulia, 2013)

Pada proceeding ICBETA 2014 dengan judul Analyze of Lung Condition Base on the Measurement of Respiration Rate and Vital Capacity of Lung Using Piezoelectric Sensor, dilakukan analisa kesehatan paru-paru pada anak-anak (usia: 8 - 12 tahun), remaja (usia: 17 - 22 tahun), dan orang dewasa (usia: 39 - 48 tahun). Hasil penelitian menunjukan bahwa faktor usia, tinggi badan dan jenis kelamin dapat mempengaruhi hasil pengukuran kapasitas paru-paru dan respirasi rate. (Kemalasari, 2014)

Kemalasari pernah merealisasikan spirometer non-invasive dengan menggunakan sensor piezoelektrik untuk mendeteksi infeksi saluran pernafasan berdasarkan pengukuran volume dan kapasitas paru-paru. Pada alat ini digunakan sensor piezoelektrik yang diletakkan didada sehingga perubahan gerakan dada pada saat bernapas dapat dideteksi dan diukur oleh 
sensor. Karena output dari sensor cukup kecil, maka dikuatkan oleh rangkaian amplifier, low pass filter, notch filter, clamper dan mikrocontroller serta Icd grafik untuk menampilkan hasil pengukuran. Alat dapat bekerja dengan baik dan dapat mendeteksi adanya infeksi saluran paru-paru, namun data hasil pengukuran belum bisa disimpan. (Kemalasari, 2016)

Dengan melihat kondisi di atas, maka pada penelitian ini dilakukan pengembangan alat spirometer non-invasive yang portable dengan menggunakan sensor piezoelektrik. Hasil pengukuran akan ditampilkan pada LCD grafik dan data hasil pengukuran akan disimpan pada $S D$ card sehingga data hasil pengukuran bisa diolah dan dianalisa lebih lanjut di PC. Pada LCD grafik, selain ditampilkan sinyal pengukuran juga ditampilkan hasil pengukuran kapasitas vital paru-paru, respirasi rate per menit dan kondisi kesehatan paru-paru secara otomatis tanpa harus menunggu beberapa hari sehingga alat ini sangat mudah digunakan oleh siapapun dan dimanapun dengan nyaman.

\section{METODOLOGI}

\subsection{Perencanaan Sistem}

Untuk merealisasikan spirometer non-invasive sebagai alat yang dapat mendeteksi kesehatan paru-paru, maka dibutuhkan perencanaan sistem. Secara umum, perencanan sistem terdiri dari bagian input yang merupakan bagian yang akan memberi input ke sistem, bagian proses yang merupakan bagian yang akan memproses sistem, dan bagian output yang akan menampilkan hasil dari sistem. Diagram blok dari perencanan sistem ditunjukkan pada Gambar 1, dan dari gambar tersebut terlihat bahwa perancangan sistem terdiri dari perancangan hardware dan perancangan software.

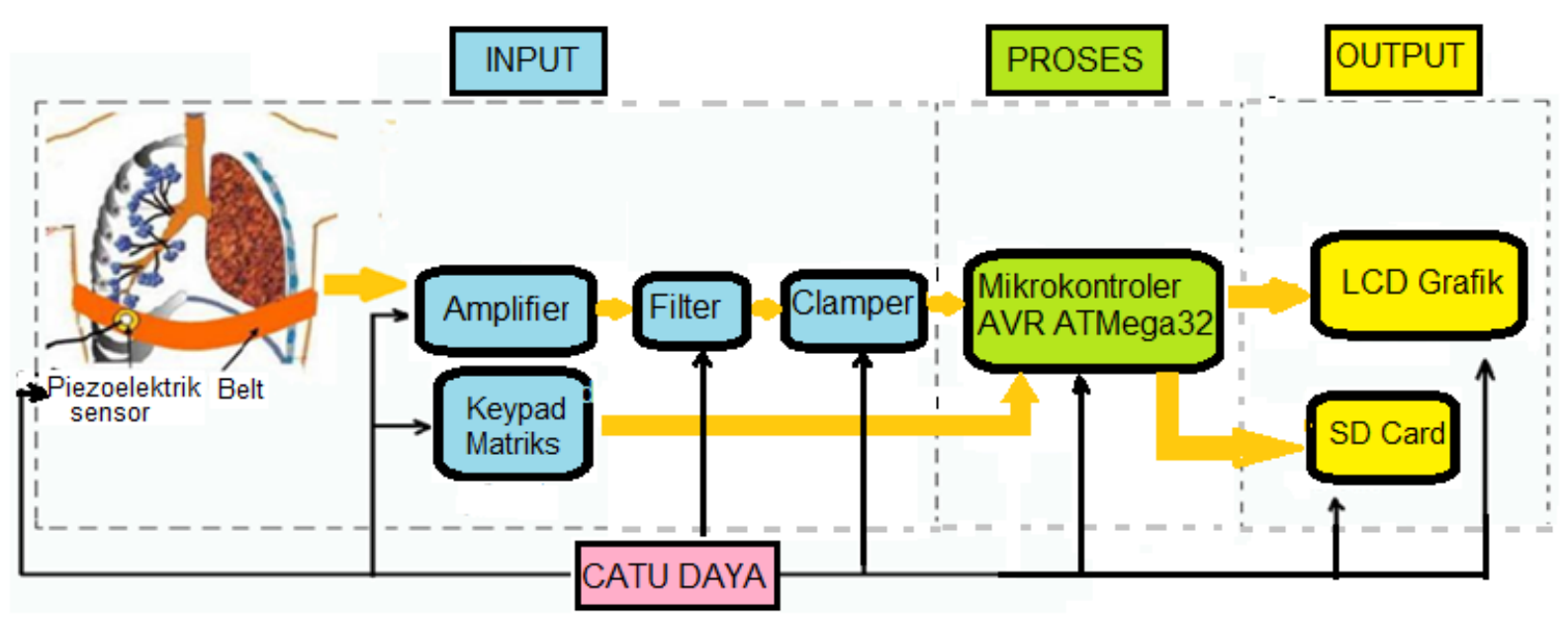

Gambar 1. Diagram Blok Sistem

\subsubsection{Input}

Pada bagian input sistem terdiri dari :

1. Sensor piezoelektrik yang dilekatkan pada belt dan diletakkan pada bagian kanan dada subyek difungsikan untuk mendeteksi perubahan tekanan di dada akibat adanya perubahan gerakan dada ketika bernafas.

2. Rangkaian Amplifier digunakan sebagai penguatan sinyal yang didapat dari sensor piezoelektrik. 
3. Rangkaian Filter digunakan untuk peredaman sinyal-sinyal tertentu (noise) yang terkandung pada sinyal respirasi.

4. Rangkaian Clamper digunakan untuk membuat sinyal dalam domain positif sehingga dapat dibaca oleh mikrokontroler.

5. Keypad matriks digunakan sebagai tombol untuk memasukkan data pasien seperti nama, usia, tinggi badan dan jenis kelamin. Selain itu juga digunakan sebagai tombol pemilihan menu.

\subsubsection{Proses}

Bagian proses atau pengolahan sinyal respirasi adalah mikrokontroler AVR ATMega32 yang digunakan untuk melakukan:

1. konversi data analog ke digital dengan memanfaatkan fasilitas ADC internal mikrokontroler ATMega32,

2. pengolahan sinyal respirasi untuk mendapatkan nilai kapasitas vital paru-paru dan nilai respirasi rate per menit (rpm),

3. pengiriman data ke LCD Grafik dan SD card.

\subsubsection{Output}

Bagian output dari sistem terdiri dari :

1. LCD (Liquid Crystal Display) Grafik yang digunakan sebagai tampilan hasil sinyal keluaran kapasitas vital paru-paru beserta analisa kesehatan paru-paru dan tampilan sinyal respirasi rate beserta nilai respirasi rate permenit dalam satuan bpm (beat per menit).

2. SD Card yang digunakan untuk menyimpan database pasien serta data hasil pengukuran.

Perencanaan tampilan hasil pengukuran dan analisa paru-paru di LCD grafik diperlihatkan pada Gambar 2, dimana pada LCD grafik akan muncul sinyal output berupa sinyal kapasitas vital paru-paru. Dari sinyal tersebut akan diketahui nilai kapasitas vital paru-paru (VC) beserta status kesehatan paru-paru dan nilai respirasi rate per menit (RPM).

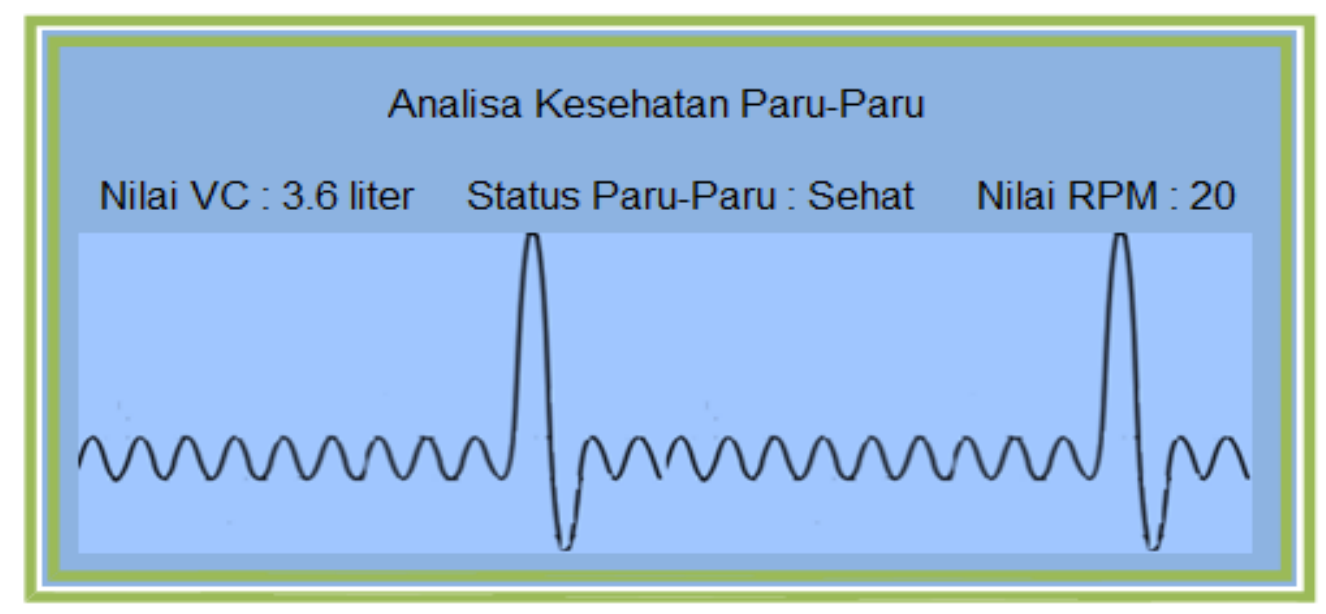

Gambar 2. Perencanaan Tampilan Hasil Pengukuran di LCD Grafik 
Nilai respirasi rate per menit dan kapasitas vital paru-paru dapat diketahui melalui hasil sinyal yang muncul pada LCD grafik, dimana sinyal terbentuk dari data hasil bacaan sensor tekanan piezoelektrik yang diukur dengan menempelkan sensor pada dada bagian kanan yang merupakan titik yang mengalami perubahan paling besar pada saat bernapas/respirasi.(Fachrial, 2012)

Data sinyal respirasi yang diterima oleh sensor piezoelektrik akan dikuatkan oleh rangkaian amplifier, kemudian sinyal difilter untuk menyaring noise dan mendapatkan sinyal yang diinginkan. Setelah itu sinyal dikirim ke mikrokontroler untuk diubah datanya dari analog ke digital melalui ADC internal mikrokontroler ATMega32 dan kemudian data sinyal diproses di mikrokontroler dan hasilnya akan ditampilkan di LCD Grafik serta disimpan dengan menggunakan memori eksternal pada mikrokontroler yaitu SD Card. Sedangkan untuk pemilihan tombol menu dan memasukkan data pasien seperti nama, usia, tinggi badan, dan jenis kelamin digunakan keypad matriks. Seluruh proses dalam system ini berbasis mikrokontroler dan memperoleh catu daya dari baterai rechargerable. Diagram alir dari perencanaan sistem ditunjukkan pada Gambar 3.

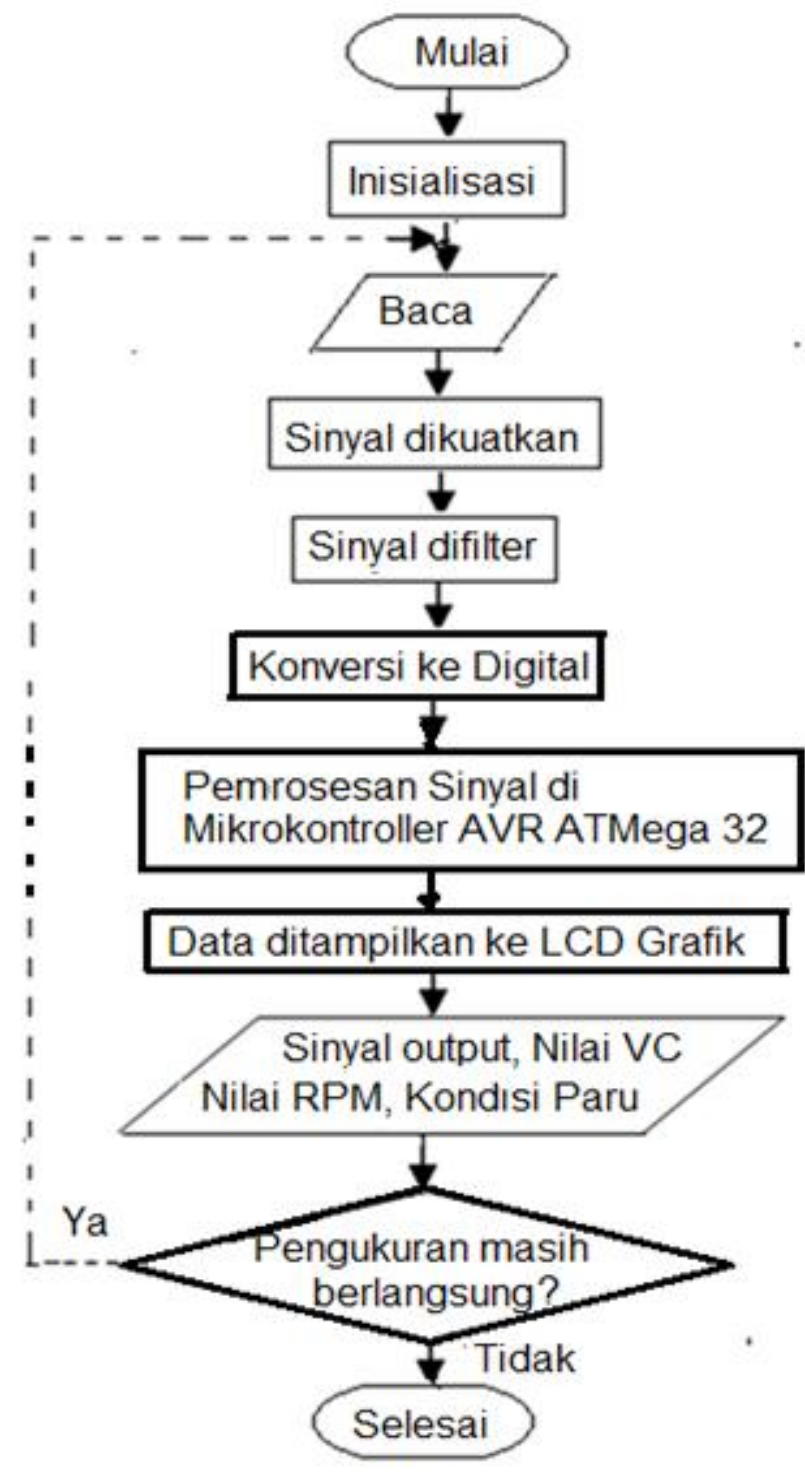

Gambar 3. Diagram Alir Perencanaan Sistem 
Pengukuran respirasi rate dilakukan dengan cara bernapas normal dan relaks selama satu menit dalam keadaan duduk, sedangkan pengukuran kapasitas vital paru-paru dilakukan dengan cara mengambil napas dalam-dalam dan menghembuskan napas sekuatnya juga dalam keadaan duduk. Untuk mengetahui kondisi kesehatan paru-paru, dilakukan perbandingan antara nilai hasil pengukuran kapasitas vital paru-paru dengan nilai prediksi kapasitas vital paru-paru dimana paru-paru terindikasi tidak sehat jika nilai kapasitas vital paru-paru hasil pengukuran kurang dari $80 \%$ dari nilai prediksi kapasitas vital paru-paru serta nilai respirasi rate kurang dari nilai respirasi rate normal. (Planzer, 2000)

\subsection{Perancangan dan Realisasi Hardware}

Untuk merealisasikan spirometer non-invasive sebagai alat yang dapat mendeteksi kesehatan paru-paru, maka diagram blok sistem dari perancangan hardware mengacu pada Gambar 1.

\subsubsection{Perancangan Rangkaian Sensor dan Amplifier.}

Rangkaian sensor yang merupakan input bagi rangkaian amplifier memiliki impedansi input yang tinggi, sehingga rangkaian ini aman digunakan karena dapat mencegah arus balik yang ditimbulkan oleh rangkaian elektronika dan objek yang diukur tidak terpengaruh secara langsung oleh aliran arus balik tersebut. Tegangan output yang dihasilkan oleh sensor piezoelektrik sangatlah kecil yaitu antara $10-80 \mathrm{mV}$, sehingga perlu dilakukan penguatan agar hasil sinyal yang keluar dapat terlihat semakin jelas terutama pada fase inspirasi dan ekspirasi.

Op-amp yang digunakan untuk rangkaian amplifier non-inverting adalah IC LM 324, dimana $\mathrm{R} 1$ yang digunakan bernilai $1 \mathrm{k} \Omega$ dan R2 berupa variabel resistor $100 \mathrm{k} \Omega$ yang dimaksudkan supaya penguatannya dapat diatur sesuai kebutuhan keluaran sinyal. Dengan tegangan input antara $10 \mathrm{mV}$ sampai $80 \mathrm{mV}$ dan penguatan maksimal 101 kali, maka didapat tegangan output sesuai kebutuhan untuk bisa dibaca mikrokontroler. Gambar rangkaian sensor piezoelektrik dan rangkaian amplifier ditunjukkan pada Gambar 4.

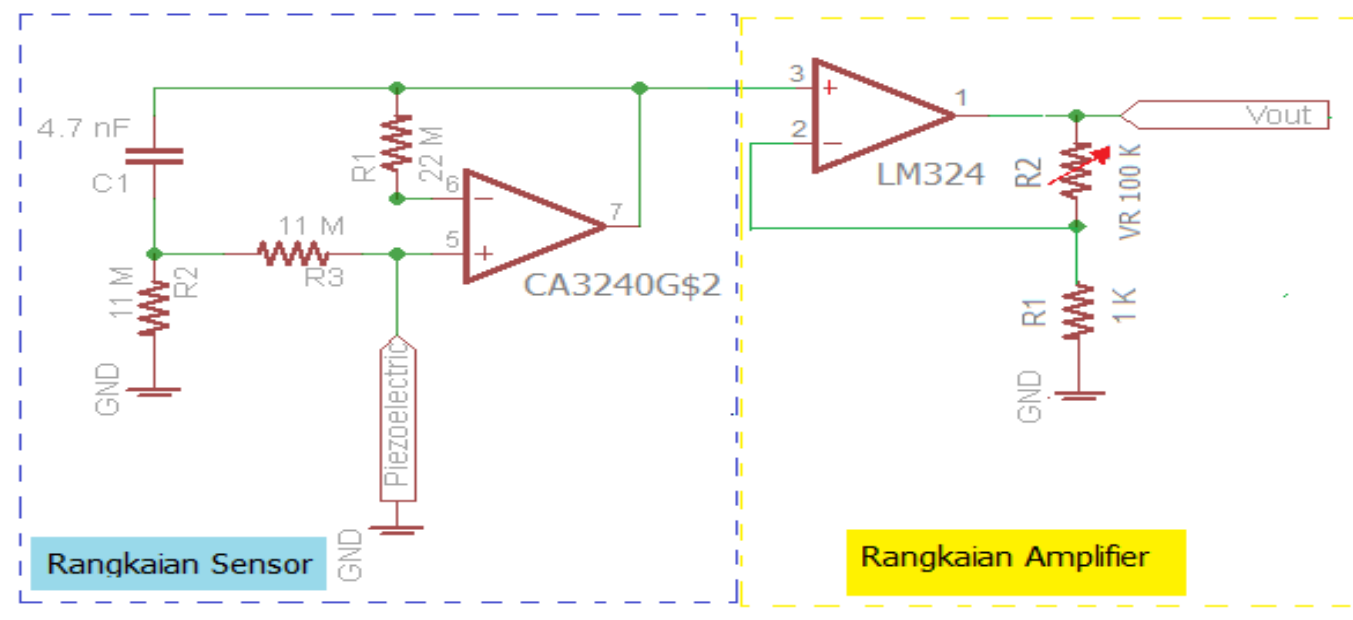

Gambar 4. Rangkaian Sensor Piezoelektrik dan Amplifier

\subsubsection{Perancangan Rangkaian Low Pass Filter.}

Low pass filter (LPF) merupakan filter yang melewatkan sinyal dengan frekuensi yang lebih rendah dari frekuensi cut off. Pada rangkaian LPF ini digunakan frekuensi cut off sebesar 15 $\mathrm{Hz}$ karena besarnya sinyal respirasi adalah disekitar $0-10 \mathrm{~Hz}$. Rangkaian LPF yang dirancang menggunakan orde 4, yang dibentuk dari 2 buah rangkaian LPF orde 2 Sallen-Key Topology dengan koefisien butterworth orde 4. Gambar dari rangkaian LPF ditunjukkan pada Gambar 5. 


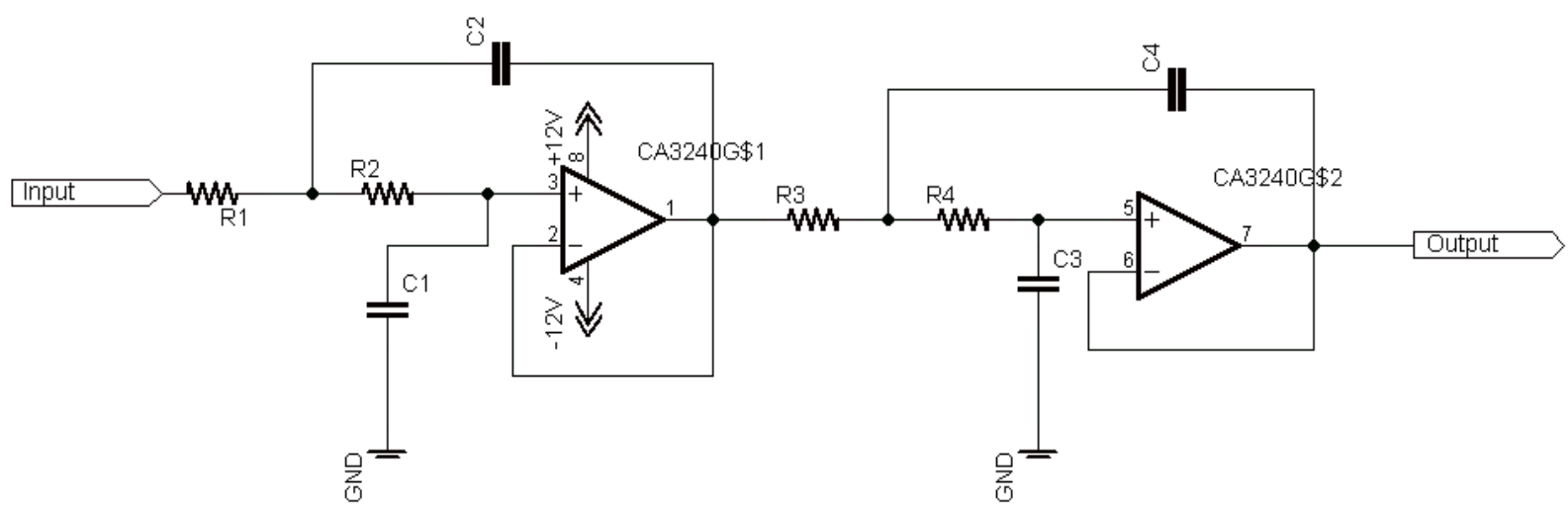

Gambar 5. Rangkaian Law Pass Filter

\subsubsection{Perancangan Rangkaian Notch Filter.}

Rangkaian notch filter digunakan untuk menghilangkan noise jala-jala frekuensi $50 \mathrm{~Hz}$ pada supply tegangan. Pada rangkaian ini ditentukan frekuensi resonansi sebesar $314 \mathrm{~Hz}$ dengan bandwidth sebesar $50 \mathrm{~Hz}$ dan faktorkualitas sebesar 6,28. Gambar dari rangkaian notch filter ditunjukkan pada Gambar 6.

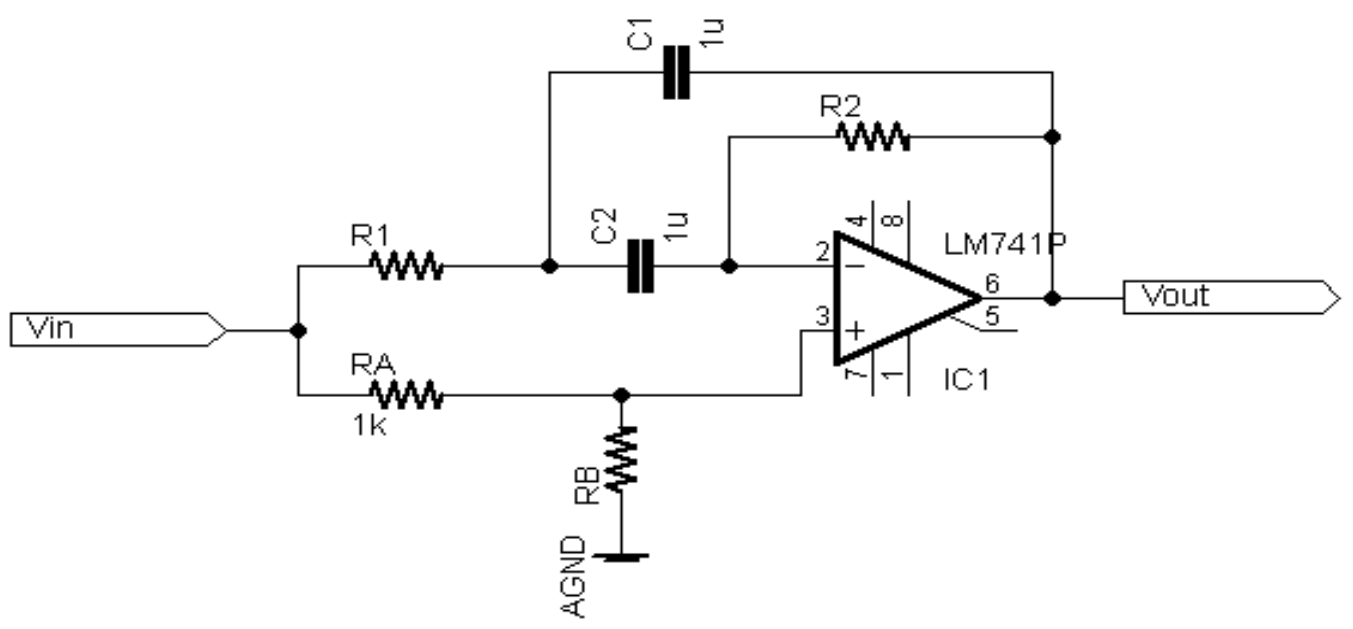

Gambar 6. Rangkaian Notch Filter

\subsubsection{Perancangan Rangkaian Clamper.}

Rangkaian clamper digunakan untuk menggeser (clamping) tegangan agar dapat diterima oleh ADC internal mikrokontroler ATMega32 dengan baik. Karena sinyal respirasi yang dihasilkan oleh rangkaian sensor, amplifier, LPF dan notch filter berada dalam range positif dan negatif, sedangkan ADC hanya dapat menerima input pada batas $0-5$ volt, oleh karena itu diperlukan rangkaian clamper untuk menaikan level sinyal respirasi ke range positif. Pada rangkaian clamper ini, variable resistor sebesar $50 \mathrm{k} \Omega$ digunakan untuk mengatur naik turunnya sinyal respirasi hingga sesuai seperti yang diinginkan. Gambar dari rangkaian clamper diperlihatkan pada Gambar 7. 


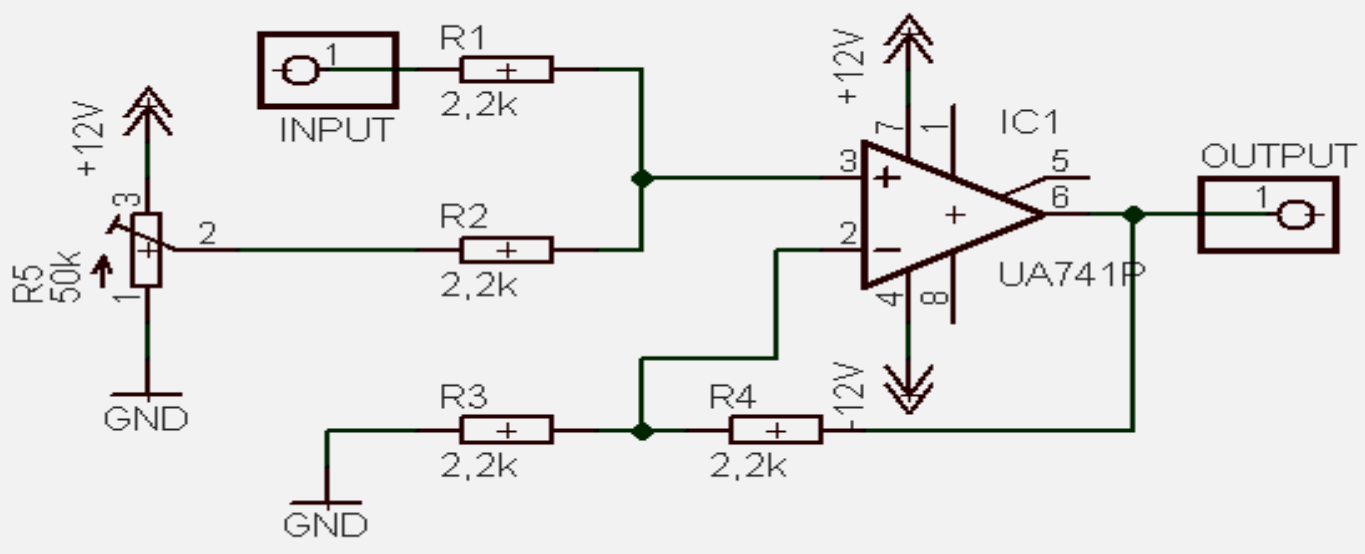

Gambar 7. Rangkaian Clamper

\subsubsection{Perancangan Rangkaian Minimum Sistem.}

Untuk merealisasikan spirometer non-invasive maka diperlukan rangkaian minimum system yang digunakan sebagai pusat untuk mengolah dan mengontrol keluaran data sinyal piezoelektrikyang akan ditampilkan melalui LCD Grafik (port A) serta mengolah data masukan dari keypad matriks (port B). Rangkaian minimum system tersusun dari mikrokontroler AVR Atmega32 yang dilengkapi dengan fasilitas port USART programmable untuk komunikasi serial, kapasitas penyimpanan memori programmable Flash sebesar 32 KiloByte, internal SRAM sebesar 2 KiloByte,1024 Bytes EEPROM, 32 port input/output, serial port, internal ADC 10 bit sebanyak 8 channel dan 3 buah timer/counter (2 buah 8 bit dan 1 buah 16 bit). Skematik dari rangkaian minimum sistem ditunjukkan pada Gambar 8 .

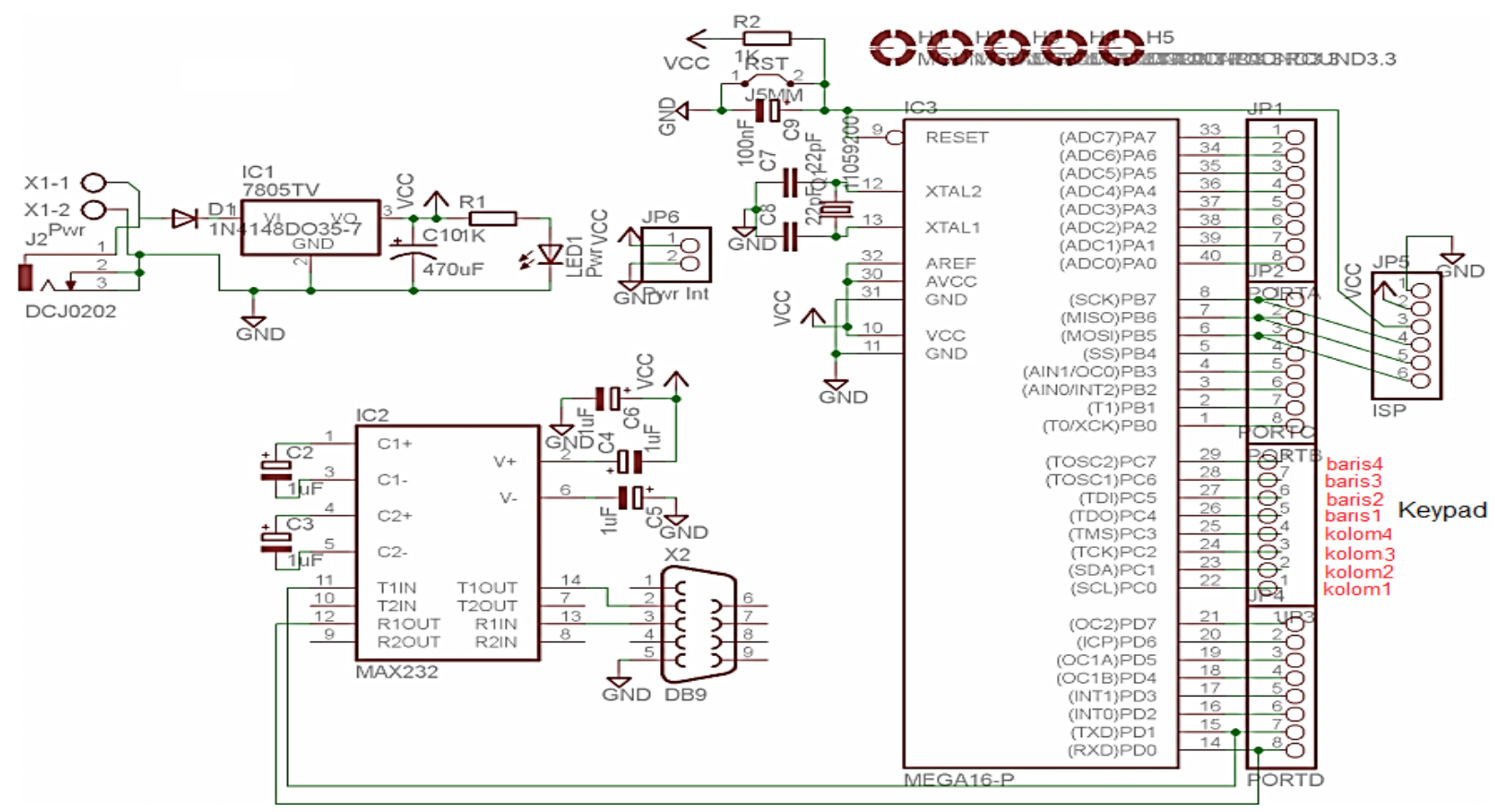

Gambar 8. Rangkaian Minimum Sistem 
2.3 Perancangan dan RealisasiSoftware.

Perangkat software diperlukan untuk memproses sinyal respirasi yang akan ditampilkan ke LCD Grafik. Perangkat software yang di inputkan ke mikrokontroller AT-Mega32 menggunakan Code Vision AVR Atmega 32 berbasis bahasa C. Data analog dari sensor piezoelektrik akan menjadi masukan untuk diproses menjadi sinyal digital yang akan ditampilkan ke LCD grafik.

\subsubsection{Program Code Vision AVR Atmega 32}

Code Vision AVR Atmega 32 merupakan software C-cross compiler, dimana program ditulis menggunakan bahasa $\mathrm{C}$ untuk mempersingkat waktu perancangan (developing time). Kompilasi dilakukan setelah program dalam bahasa $\mathrm{C}$ ditulis, dan jika tidak ada kesalahan (error) baru dilakukan proses download secara ISP. Gambar 9 merupakan tampilan Code Vision AVR dalam melakukan setting ADC dengan menggunakan 8 bit data, dimana Transfer data dilakukan dengan pembacaan ADC pada port $\mathrm{A}(1)$ dengan koefisien delay 22,2 ms.

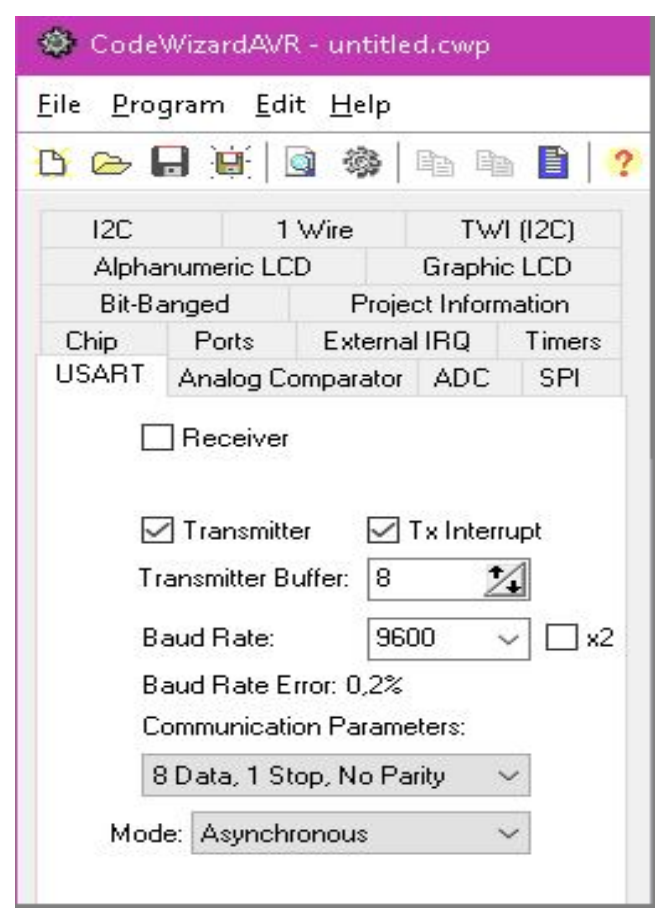

Gambar 9. Tampilan Pemilihan Aplikasi AVR

\subsubsection{Perancangan Algoritma Deteksi Kondisi Kesehatan Paru-Paru}

Untuk deteksi kondisi kesehatan paru-paru, diperlukan data masukan dari orang yang akan diukur. Keypad matrik digunakan sebagai tombol untuk memasukkan data dari orang yang akan diukur yaitu data berupa nama, umur, tinggi badan serta jenis kelamin, dan juga sebagai tombol untuk pemilihan menu. Teknik untuk membaca data dari keypad menggunakan teknik scanning, dimana untuk akses keypad, terlebih dahulu ditentukan kolom sebagai output dari mikrokontroler dan baris sebagai input ke mikrokontroler.

Pilihan menu pada sistem ada 3 yaitu:

1. Pengukuran VC,

2. Pengukuran RPM, dan

3. Data VC dan RPM. 
Menu 1 digunakan untuk pengukuran VC (Kapasitas Vital Paru-paru) dengan cara menarik napas dalam-dalam dan menghembus napas sekuatnya dalam keadaan duduk. Setelah pengukuran VC selesai, maka nilai hasil pengukuran kapasitas vital paru-paru dan kondisi kesehatan paru-paru dapat langsung diketahui.

Menu 2 digunakan untuk mengukur respirasi rate per menit (RPM), dengan cara bernafasan normal selama 15 detik. Setelah pengukuran RPM selesai,maka sinyal pengukuran dan nilai hasil pengukuran respirasi rate per menit dapat langsung diketahui.

Menu 3 digunakan untuk menampilkan biodata orang yang diukur dan data hasil pengukuran kapasitas vital paru-paru serta respirasi rate per menit yang sudah dilakukan. Diagram alir untuk deteksi kondisi kesehatan paru-paru yang ditampilkan di LCD grafik ditunjukkan pada Gambar 10.

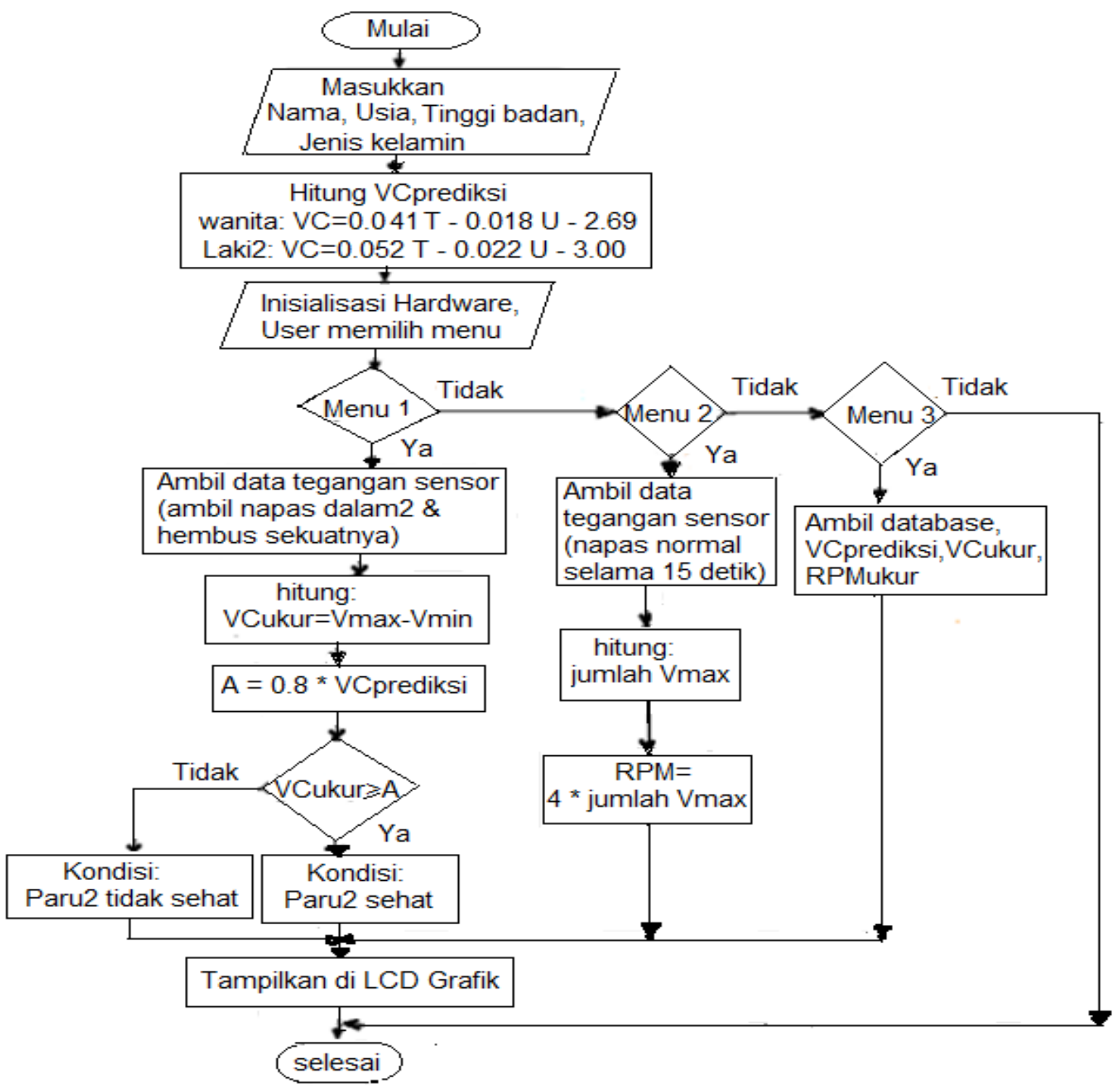

Gambar 10. Diagram Alir Deteksi Kondisi Kesehatan Paru-Paru

Deteksi kesehatan paru-paru ditentukan berdasarkan perbandingan antara hasil pengukuran kapasitas paru-paru alat dengan nilai prediksi kapasital vital paru-paru. Jenis kelamin, usia, 
dan tinggi badan akan mempengaruhi nilai prediksi kapasitas vital paru-paru. Untuk menentukan nilai prediksi kapasitas vital paru-paru (VCprediksi) digunakan Persamaan (1) untuk laki-laki dan Persamaan (2) untuk perempuan.(Planzer, 2000), (Faridah, 2011)

$$
\begin{aligned}
& \text { Untuk Laki-Laki: } V C_{\text {prediksi }}=(0.052 x T)-(0.022 x U)-3.00 \\
& \text { Untuk Perempuan: } V C_{\text {prediksi }}=(0.041 x T)-(0.018 x U)-2.69
\end{aligned}
$$

$$
\begin{aligned}
& \text { dimana : } \\
& \mathrm{T}=\text { tinggi badan }(\mathrm{cm}) \\
& \mathrm{U}=\text { usia (tahun) }
\end{aligned}
$$

Katagori kesehatan paru-paru seseorang ditetapkan berdasarkan perbandingan antara nilai prediksi kapasitas vital paru-paru (VCprediksi) pada Persamaan (1) dan (2) dengan nilai kapasitas vital paru-paru hasil pengukuran. Jika nilai kapasitas paru-paru hasil pengukuran sama atau lebih dari $80 \%$ dari nilai prediksi kapasitas vital paru-paru (VCprediksi), maka dideteksi kondisi paru-paru sehat (normal).(Planzer, 2000)

\section{PENGUJIAN SISTEM}

Pengujian sistem secara keseluruhan dilakukan dengan cara mengintegrasikan seluruh subsistem hardware dan software. Tujuan dari pengujian sistem adalah untuk mengetahui apakah sistem yang dirancang sudah dapat bekerja atau belum. Pengujian dilakukan pada rangkaian sensor dan amplifier, rangkaian low pass filter, rangkaian notch filter dan rangkaian clamper.

\subsection{Pengujian Rangkain Sensor Piezoelektrik dan Amplifier}

Input dari rangkaian adalah data dari sensor piezoelektrik yang direkatkan pada belt dan diletakkan di dada subyek, sedangkan ouput dari rangkaian dilihat pada oscilloscope. Hasil pengujian dari rangkaian sensor dan amplifier yang ditampilkan pada oscilloscope saat subyek duduk tenang sambil menarik nafas dalam-dalam dan menghembus sekuatnya ditunjukkan pada Gambar 11.

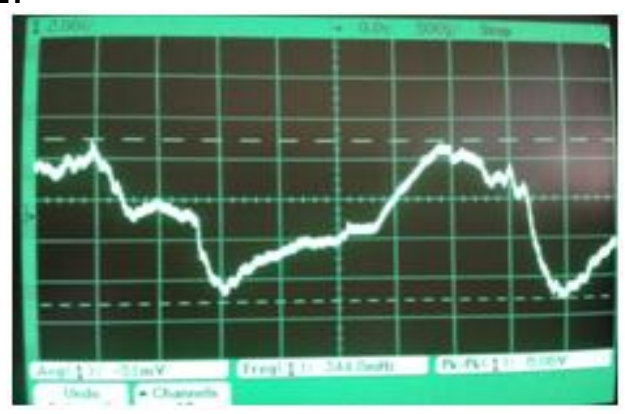

\section{Gambar 11. Pengujian Rangkaian Sensor dan Amplifier}

Hasil pengujian memperlihatkan bahwa rangkaian sensor piezoelektrik dan amplifier telah bekerja dengan baik. Sensor piezoelektrik sensitif terhadap adanya perubahan tekanan pada dada saat proses pernafasan. Besarnya tegangan output yang dihasilkan bergantung pada besarnya tekanan pada saat bernafas. Semakin besar tarikan dan hembusan nafas pada saat subyek bernafas maka semakin besar pula tegangan output yang dihasilkan. Tegangan output yang dihasilkan oleh sensor sebesar $10-80 \mathrm{mv}$, sehingga perlu adanya penguatan 
sebesar 100 kali agar ouput yang dihasilkan memiliki tegangan yang lebih besar dan dapat diolah dan diproses lebih lanjut di ADC internal mikrokontroler.

\subsection{Pengujian Rangkaian Low Pass Filter}

Tujuan pengujian rangkaian low pass filter adalah untuk mengetahui frekuensi cut-off dan respon frekuensinya. Pengujian dilakukan dengan memberi tegangan input sebesar 1 Volt melalui function generator dan memberikan kenaikan frekuensi dari $0,5 \mathrm{~Hz}$ sampai $100 \mathrm{~Hz}$. Karakteristik dari rangkaian low pass filter orde 4 dengan frekuensi cut-off sebesar $15 \mathrm{~Hz}$ dapat dilihat pada Gambar 12. Berdasarkan response pada Gambar 12, rangkaian dapat meloloskan sinyal di bawah frekuensi $15 \mathrm{~Hz}$ sehingga rangkaian low pass filter sudah dapat berjalan sesuai dengan perencanaan.

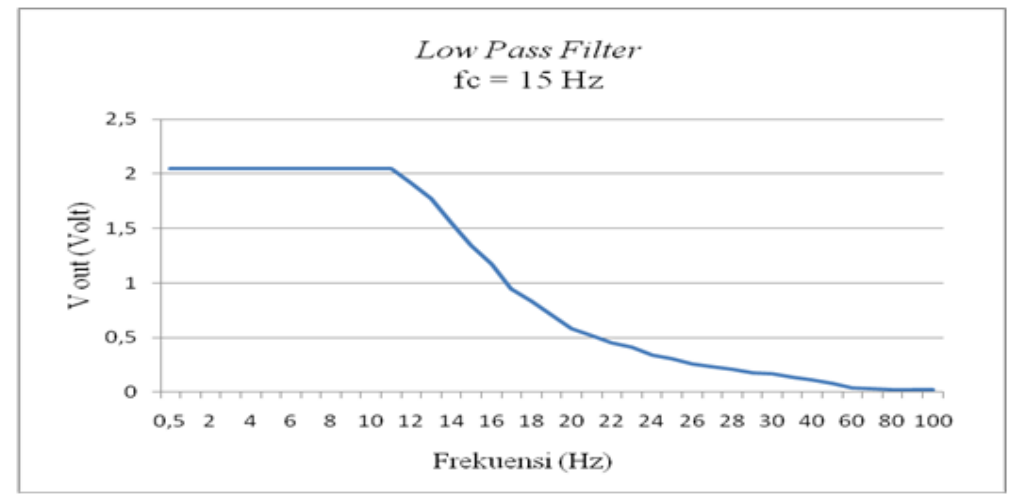

Gambar 12. Respon Frekuensi Low Pass Filter

\subsection{Pengujian Rangkaian Notch Filter}

Tujuan rangkaian notch filter adalah untuk menghilangkan frekuensi jala-jala PLN sebesar 50 $\mathrm{Hz}$. Pengujian dilakukan dengan memberi tegangan input sebesar $500 \mathrm{mV}$ melalui function generator dan memberikan kenaikan frekuensi dari 0,5 sampai $100 \mathrm{~Hz}$. Karakteristik dari rangkaian notch filter dapat dilihat pada Gambar 13. Dari respon dapat dilihat bahwa setelah frekuensi $20 \mathrm{~Hz}$ tegangan output mengalami penurunan sampai pada frekuensi $50 \mathrm{~Hz}$ yaitu sebesar 0,075 Volt, kemudian setelah frekuensi $50 \mathrm{~Hz}$ terlewati maka seiring dengan kenaikan frekuensi, tegangan output yang dihasilkan mengalami kenaikan sampai akhirnya mengalami saturasi sehingga rangkaian Notch Filter dapat berfungsi dengan bagus.

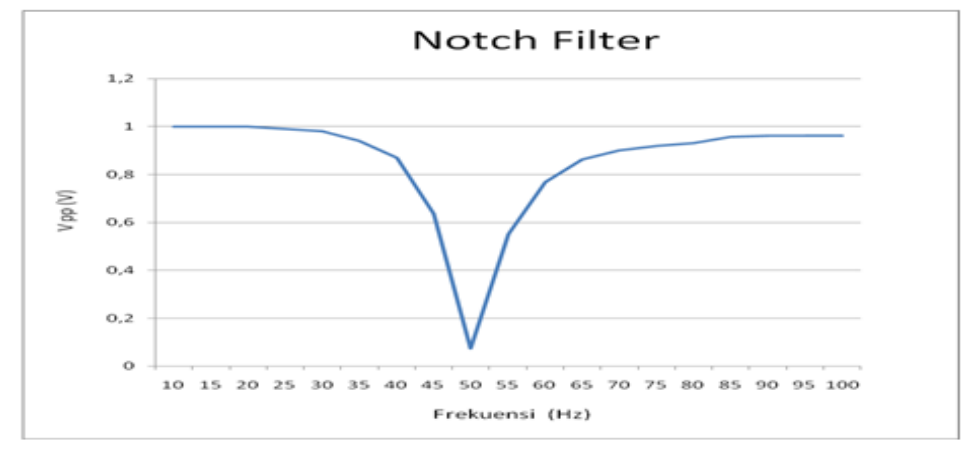

Gambar 13. Respon Frekuensi Notch Filter

Pengujian keseluruhan sistem (hardware), integrasi pada rangkaian mendapat supply tegangan dari power supply sebesar 9 volt. Hasil sinyal dari integrasi rangkaian keseluruhan sistem yang ditampilkan pada oscilloscope saat subyek bernapas dalam-dalam ditunjukkan pada Gambar 14. 


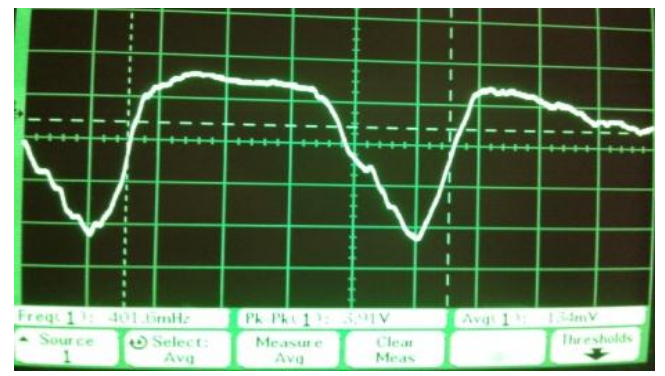

\section{Gambar 14. Hasil Pengujian saat Bernafas Dalam-dalam}

\subsection{Realisasi Spirometer Non-invasive}

Berdasarkan hasil rancangan diatas, maka direalisasikan spirometer non-invasive dengan menggunakan sensor piezoelektrik untuk mendeteksi kesehatan paru-paru. Spirometer ini berukuran kecil (panjang:18,5 cm, lebar:15 cm dan tinggi: $8 \mathrm{~cm}$ ), mendapat catu daya dari baterai rechargerable dan portable. Tampilan rangka spirometer ditunjukkan pada Gambar 15, sedangkan tampilan hasil pengukuran kapasitas vital paru-paru pada LCD grafik ditunjukkan pada Gambar 16.

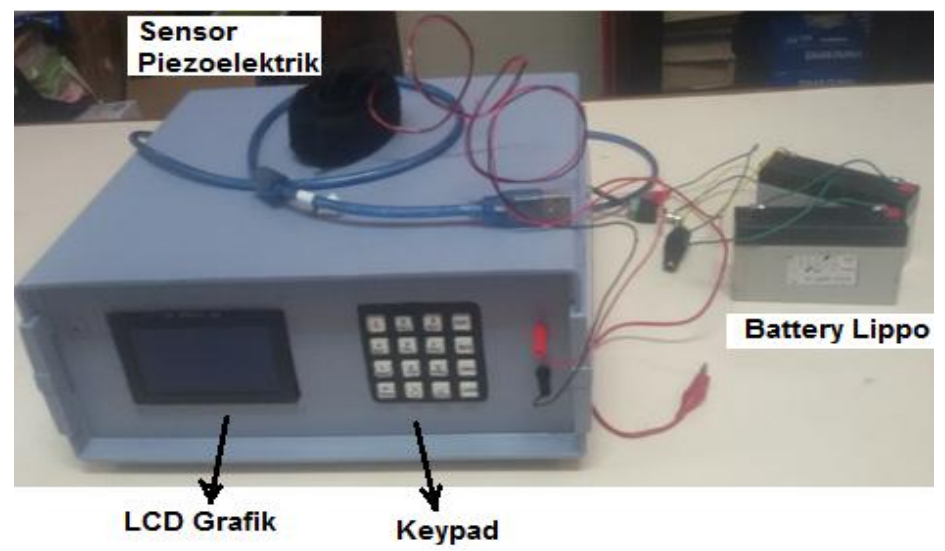

Gambar 15. Spirometer Non-invasive (realisasi)
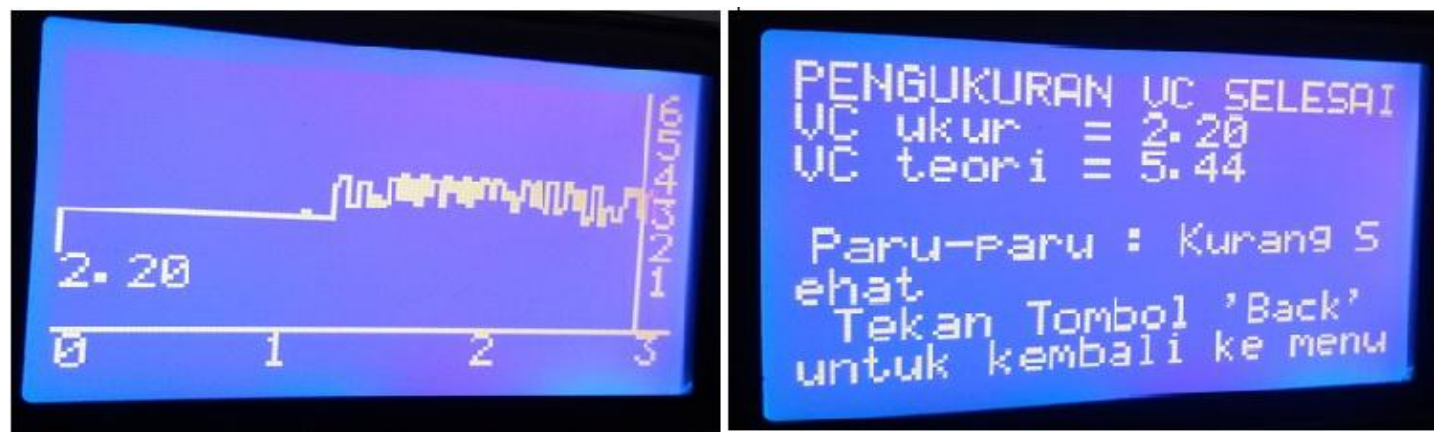

Gambar 16. Tampilan Pengukuran Kapasitas Vital Paru-Paru (VC) pada LCD Grafik

\subsubsection{Pengujian Catu Daya}

Catu daya yang digunakan pada spirometer non-invasive adalah 1 buah baterai Lipo (Lithium-Polimer) yang mempunyai kapasitas dan tegangan baterai $1000 \mathrm{mAh}, 12 \mathrm{~V}$ dengan discharge rate sebesar 20-30 C. Discharge rate berguna untuk mengetahui seberapa besar baterai tersebut dapat menahan beban maksimum. Karena baterai memiliki rating discharge maksimum sebesar $30 \mathrm{C}$ maka berarti baterai dapat menahan beban maksimum 
hingga $500 \mathrm{~mA}$ yang artinya energy baterai sebesar $1000 \mathrm{mAh}$ akan terkuras habis dalam waktu 2 menit. Jika baterai hanya mensuplai arus sistem sebesar 400mAh maka baterai dapat bertahan selama 2 jam 30 menit.

\subsubsection{Pengujian SD Card}

$S D$ card berfungsi untuk menyimpan data semua informasi yang telah didapatkan dari sensor yang terhubung pada alat pembuatan data logger. Data yang diambil dari semua sistem akan disimpan dalam format xls. Format xls ini dapat dibuka melalui Microsoft Excel. Pemilihan format xls adalah untuk mempermudah pengolahan data. Gambar 17 menunjukkan tampilan data yang disimpan dalam SD card. Gambar ini membuktikan bahwa modul $S D$ card dapat mendeteksi dan menyimpan nilai ADC dari sensor piezoelektrik.

\begin{tabular}{|c|c|c|c|c|c|}
\hline 4 & A & B & C & D & $E$ \\
\hline 6081 & 11 & $23 / 06 / 2014$ & $13: 29: 05$ & 0 & \\
\hline 6082 & 12 & $23 / 06 / 2014$ & $13: 29: 07$ & 0 & \\
\hline 6083 & 13 & $23 / 06 / 2014$ & $13: 29: 09$ & 0 & \\
\hline 6084 & 14 & $23 / 06 / 2014$ & $13: 29: 11$ & 0 & \\
\hline 6085 & 15 & $23 / 06 / 2014$ & $13: 29: 13$ & 0 & \\
\hline 6086 & 16 & $23 / 06 / 2014$ & $13: 29: 15$ & 6 & \\
\hline 6087 & 17 & $23 / 06 / 2014$ & $13: 29: 17$ & 67 & \\
\hline 6088 & 18 & $23 / 06 / 2014$ & $13: 29: 19$ & 170 & \\
\hline 6089 & 19 & $23 / 06 / 2014$ & $13: 29: 21$ & 271 & \\
\hline 6090 & 20 & $23 / 06 / 2014$ & $13: 29: 23$ & 356 & \\
\hline 6091 & 21 & $23 / 06 / 2014$ & $13: 29: 25$ & 441 & \\
\hline 6092 & 22 & $23 / 06 / 2014$ & $13: 29: 27$ & 504 & \\
\hline 6093 & 23 & $23 / 06 / 2014$ & $13: 29: 30$ & 651 & \\
\hline 6094 & 24 & $23 / 06 / 2014$ & $13: 29: 32$ & 829 & \\
\hline 6095 & 25 & $23 / 06 / 2014$ & $13: 29: 34$ & 973 & \\
\hline 6096 & 26 & $23 / 06 / 2014$ & $13: 29: 36$ & 1023 & \\
\hline 6097 & 27 & $23 / 06 / 2014$ & $13: 29: 38$ & 1023 & \\
\hline 6098 & 28 & $23 / 06 / 2014$ & $13: 29: 40$ & 1023 & \\
\hline 6099 & 29 & $23 / 06 / 2014$ & $13: 29: 42$ & 1023 & \\
\hline 6100 & 30 & $23 / 06 / 2014$ & $13: 29: 44$ & 1023 & \\
\hline 6101 & 31 & $23 / 06 / 2014$ & $13: 29: 46$ & 1023 & \\
\hline 6102 & 32 & $23 / 06 / 2014$ & $13: 29: 48$ & 1023 & \\
\hline
\end{tabular}

\section{Gambar 17. Data dari SD Card}

\subsubsection{Pengujian Sistem Pengukuran Kapasitas Vital Paru-paru}

Pengukuran kapasitas vital paru-paru dilakukan pada 20 subyek yang terdiri dari 4 anak dengan usia 8 - 11 tahun, 11 remaja dengan usia 17 - 22 tahun, dan 5 orang dewasa dengan usia 39 - 52 tahun. Pengujian sistem pengukuran dilakukan dengan cara membandingkan pengukuran kapasitas vital paru-paru menggunakan spirometer noninvasive hasil rancangan terhadap pengukuran kapasitas vital paru-paru dengan menggunakan alat spirometer Biopac system. Hasil pengukuran ditunjukkan pada Tabel 1.

$$
\operatorname{Error}(\%)=\left|\frac{\text { VCukur Biopac }- \text { VCukur Alat }}{\text { VCukur Biopac }}\right| x 100 \%
$$


Tabel 1. Hasil Pengujian Kapasitas Vital Paru-Paru

\begin{tabular}{|c|c|c|c|c|c|c|c|}
\hline Subyek & $\begin{array}{c}\text { Jenis } \\
\text { Kelamin } \\
\text { (L/P) }\end{array}$ & $\begin{array}{c}\text { Umur } \\
\text { (tahun) }\end{array}$ & $\begin{array}{c}\text { Tinggi } \\
\text { badan } \\
(\mathbf{c m})\end{array}$ & $\begin{array}{c}\text { VCukur } \\
\text { (alat) } \\
\text { (liter) }\end{array}$ & $\begin{array}{c}\text { VCukur } \\
\text { (Biopac) } \\
\text { (liter) }\end{array}$ & $\begin{array}{l}\text { Persen } \\
\text { Error (\%) }\end{array}$ & $\begin{array}{l}\text { Persen } \\
\text { berhasil } \\
(\%)\end{array}$ \\
\hline 1 & $\mathrm{P}$ & 8 & 124 & 3.87 & 3.83 & 1.04 & 98.96 \\
\hline 2 & $\mathrm{P}$ & 11 & 155 & 4 & 3.92 & 2.04 & 97.96 \\
\hline 3 & $\mathrm{~L}$ & 11 & 150 & 3.93 & 3.95 & 0.51 & 99.49 \\
\hline 4 & $\mathrm{P}$ & 11 & 145 & 4.13 & 4.23 & 2.36 & 97.64 \\
\hline 5 & $\mathrm{P}$ & 17 & 168 & 4.4 & 4.25 & 3.53 & 96.47 \\
\hline 6 & $\mathrm{~L}$ & 20 & 168 & 4.27 & 4.32 & 1.16 & 98.84 \\
\hline 7 & $\mathrm{~L}$ & 20 & 170 & 3,3 & 3.35 & 1.49 & 98.51 \\
\hline 8 & $\mathrm{~L}$ & 21 & 168 & 4.2 & 4.05 & 3.7 & 96.3 \\
\hline 9 & $\mathrm{~L}$ & 21 & 173 & 4.27 & 4.2 & 1.67 & 98.33 \\
\hline 10 & $\mathrm{P}$ & 22 & 160 & 4.13 & 4.15 & 0.48 & 99.52 \\
\hline 11 & $\mathrm{~L}$ & 22 & 165 & 3.95 & 4 & 1.25 & 98.75 \\
\hline 12 & $\mathrm{~L}$ & 23 & 172 & 2.2 & 2.25 & 2.22 & 97.78 \\
\hline 13 & $\mathrm{P}$ & 22 & 154 & 3.6 & 3.75 & 4 & 96 \\
\hline 14 & $\mathrm{P}$ & 22 & 158 & 3 & 3.15 & 4.76 & 95.24 \\
\hline 15 & $\mathrm{~L}$ & 25 & 170 & 4.54 & 4.62 & 1.73 & 98.27 \\
\hline 16 & $\mathrm{P}$ & 40 & 155 & 3.93 & 3.85 & 2.08 & 97.92 \\
\hline 17 & $\mathrm{P}$ & 48 & 148 & 3.23 & 3.15 & 2.54 & 97.46 \\
\hline 18 & $\mathrm{P}$ & 39 & 175 & 3.4 & 3.3 & 3.03 & 96.97 \\
\hline 19 & $\mathrm{P}$ & 40 & 158 & 2.9 & 3 & 3.33 & 96.67 \\
\hline 20 & $\mathrm{~L}$ & 52 & 172 & 2.12 & 2.2 & 3.63 & 96.37 \\
\hline Selisih rata-rata persentase error dan berhasil & 2.33 & 97.67 \\
\hline
\end{tabular}

Besarnya persentase error pada Tabel 1 dihitung berdasarkan Persamaan (3). Besarnya persentase kesalahan disebabkan karena kondisi subyek pada saat pengukuran kurang tenang dan sensor piezoelektrik sangat sensitif terhadap adanya perubahan tekanan. Oleh karena itu pada saat subyek melakukan pengukuran diharapkan dalam kondisi yang tenang dan diam. Sedangkan grafik dari hasil pengukuran pada Tabel 1 ditunjukkan pada Gambar 18.

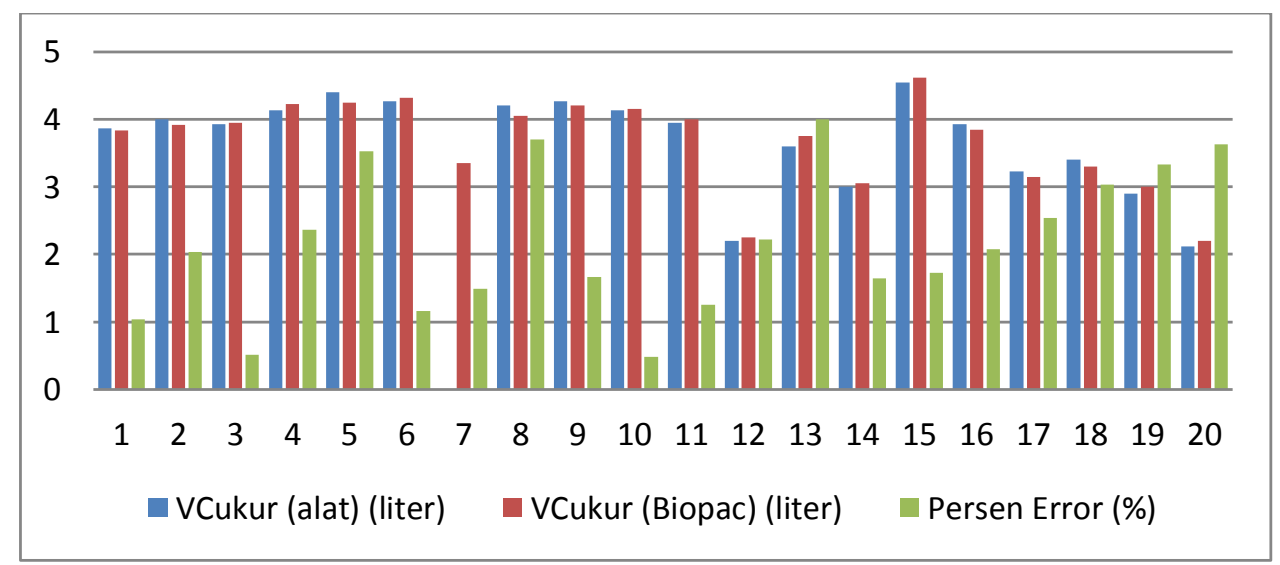

Gambar 18. Grafik Data Pengukuran Kapasitas Vital Paru-Paru 


\subsubsection{Pengujian Sistem Pengukuran Respirasi Rate Per Menit}

Pengujian sistem pengukuran respirasi rate per menit dilakukan dengan cara membandingkan pengukuran respirasi rate menggunakan spirometer non-invasive hasil rancangan terhadap pengukuran respirasi rate secara manual yaitu menghitung banyaknya subyek menghirup napas selama 1 menit dengan menggunakan stopwatch. Hasil pengukuran respirasi rate per menit ditunjukkan pada Tabel 2. Besar persentase error pada Tabel 2 dihitung berdasarkan Persamaan (4). Sedangkan grafik dari hasil pengukuran pada Tabel 2 ditunjukkan pada Gambar 19.

$$
\text { Error }(\%)=\left|\frac{R P M \text { Manual }- \text { RPM Pengukuran }}{\text { RPM Manual }}\right| \times 100 \%
$$

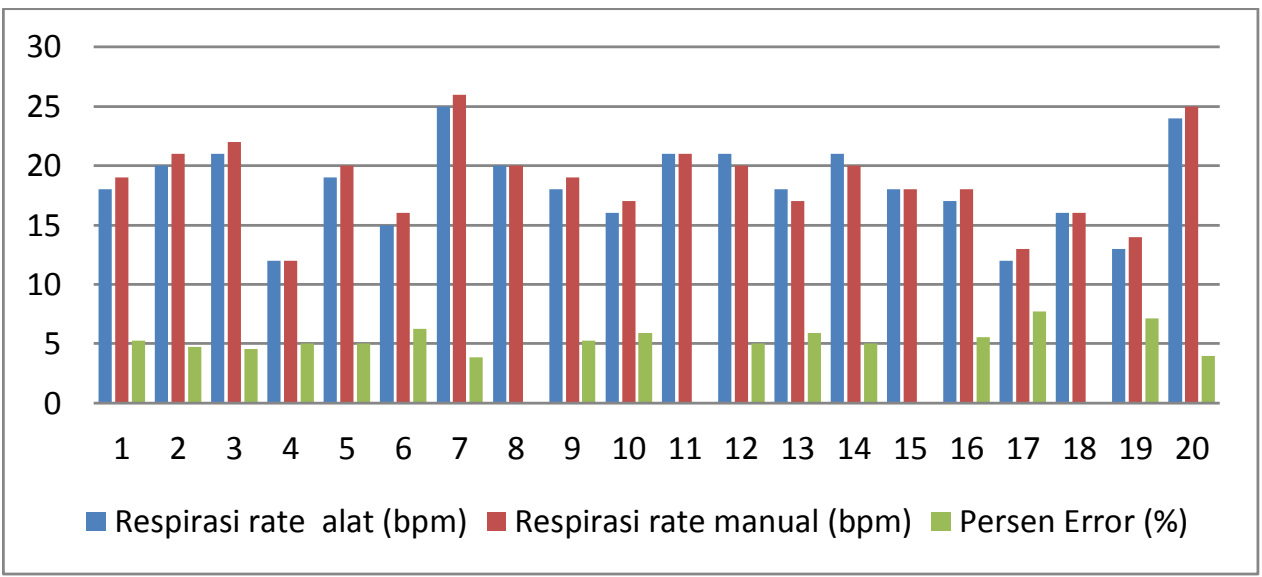

Gambar 19. Grafik Data Pengukuran Respirasi Rate per menit

Tabel 2. Hasil Pengujian Respirasi Rate per menit

\begin{tabular}{|c|c|c|c|c|c|c|c|}
\hline Subyek & $\begin{array}{c}\text { Jenis } \\
\text { Kelamin } \\
\text { (L/P) }\end{array}$ & $\begin{array}{c}\text { Umur } \\
\text { (tahun) }\end{array}$ & $\begin{array}{c}\text { Tinggi } \\
\text { badan } \\
\text { (cm) }\end{array}$ & $\begin{array}{l}\text { Respirasi } \\
\text { rate alat } \\
\text { (bpm) }\end{array}$ & $\begin{array}{l}\text { Respirasi } \\
\text { rate manual } \\
\text { (bpm) }\end{array}$ & $\begin{array}{l}\text { Persen } \\
\text { Error } \\
(\%)\end{array}$ & $\begin{array}{l}\text { Persent } \\
\text { berhasil } \\
(\%)\end{array}$ \\
\hline 1 & P & 8 & 124 & 18 & 19 & 5.26 & 94.74 \\
\hline 2 & P & 11 & 155 & 20 & 21 & 4.76 & 95.24 \\
\hline 3 & L & 11 & 150 & 21 & 22 & 4.54 & 95.46 \\
\hline 4 & P & 11 & 145 & 12 & 12 & 5 & 95.00 \\
\hline 5 & P & 17 & 168 & 19 & 20 & 5 & 95.00 \\
\hline 6 & L & 20 & 168 & 15 & 16 & 6.25 & 93.75 \\
\hline 7 & L & 20 & 170 & 25 & 26 & 3.84 & 96.16 \\
\hline 8 & L & 21 & 168 & 20 & 20 & 0 & 100.00 \\
\hline 9 & L & 21 & 173 & 18 & 19 & 5.26 & 94.74 \\
\hline 10 & P & 22 & 160 & 16 & 17 & 5.88 & 94.12 \\
\hline 11 & L & 22 & 165 & 21 & 21 & 0 & 100.00 \\
\hline 12 & L & 23 & 172 & 21 & 20 & 5 & 95.00 \\
\hline 13 & P & 22 & 154 & 18 & 17 & 5.9 & 94.10 \\
\hline 14 & P & 22 & 158 & 21 & 20 & 5 & 95.00 \\
\hline 15 & L & 25 & 170 & 18 & 18 & 0 & 100.00 \\
\hline 16 & P & 40 & 155 & 17 & 18 & 5.56 & 94.44 \\
\hline 17 & P & 48 & 148 & 12 & 13 & 7.69 & 92.31 \\
\hline 18 & P & 39 & 175 & 16 & 16 & 0 & 100.00 \\
\hline 19 & P & 40 & 158 & 13 & 14 & 7.14 & 92.86 \\
\hline 20 & L & 52 & 172 & 24 & 25 & 4 & 96.00 \\
\hline Selisih rata-rata persentase error dan berhasil & 4.30 & 95.70 \\
\hline
\end{tabular}




\subsubsection{Pengujian Keseluruhan Sistem}

Tujuan pengujian secara keseluruhan system adalah untuk melihat hasil dari masing-masing subsistem setelah diintegrasikan dan melihat hasil keluaran secara keseluruhan dari system yang telah dirancang dan direalisasikan. Pengujian keseluruhan system ini berupa pengujian terhadap software dan konektivitas antara software dan hardware. Hasil pengujian keseluruhan system ditunjukkan pada Tabel 3.

Pada Tabel 3, nilai prediksi kapasitas vital paru-paru disingkat menjadi $\mathrm{VC}_{\text {prediksi }}$ yang dihitung dengan menggunakan Persamaan (1) dan (2), sedangkan kondisi paru-paru dideteksi tidak sehat jika nilai hasil ukur kapasitas vital paru-paru kurang dari $80 \%$ dari nilai prediksi kapasitas vital paru-paru.(Planzer, 2000)

Tabel 3. Hasil Pengujian Keseluruhan Sistem

\begin{tabular}{|c|c|c|c|c|c|c|c|}
\hline Subyek & $\begin{array}{c}\text { Jenis } \\
\text { Kelamin } \\
\text { (L/P) }\end{array}$ & $\begin{array}{c}\text { Umur } \\
\text { (tahun) }\end{array}$ & $\begin{array}{c}\text { Tinggi } \\
\text { badan } \\
\text { (cm) }\end{array}$ & $\begin{array}{l}\text { Respirasi } \\
\text { rate alat } \\
\text { (rpm) }\end{array}$ & $\begin{array}{l}\text { VCukur } \\
\text { (alat) (liter) }\end{array}$ & $\begin{array}{l}\text { VCprediksi } \\
\text { (liter) }\end{array}$ & Kondisi Paru \\
\hline 1 & $\mathrm{P}$ & 8 & 124 & 18 & 3.87 & 2.25 & sehat \\
\hline 2 & $\mathrm{P}$ & 11 & 155 & 20 & 4 & 3.47 & sehat \\
\hline 3 & $\mathrm{~L}$ & 11 & 150 & 21 & 3.93 & 4.56 & sehat \\
\hline 4 & $\mathrm{P}$ & 11 & 145 & 12 & 4.13 & 4.3 & sehat \\
\hline 5 & $\mathrm{P}$ & 17 & 168 & 19 & 4.4 & 3.89 & sehat \\
\hline 6 & $\mathrm{~L}$ & 20 & 168 & 15 & 4.27 & 5.3 & sehat \\
\hline 7 & $\mathrm{~L}$ & 20 & 170 & 25 & 3,3 & 5.4 & tidak sehat \\
\hline 8 & $\mathrm{~L}$ & 21 & 168 & 20 & 4.2 & 5.27 & sehat \\
\hline 9 & $\mathrm{~L}$ & 21 & 173 & 18 & 4.27 & 5.53 & sehat \\
\hline 10 & $\mathrm{P}$ & 22 & 160 & 16 & 4.13 & 3.47 & sehat \\
\hline 11 & $\mathrm{~L}$ & 22 & 165 & 21 & 3.95 & 5.09 & tidak sehat \\
\hline 12 & $\mathrm{~L}$ & 23 & 172 & 21 & 2.2 & 5.44 & tidak sehat \\
\hline 13 & $\mathrm{P}$ & 22 & 154 & 18 & 3.6 & 3.23 & sehat \\
\hline 14 & $\mathrm{P}$ & 22 & 158 & 21 & 3 & 3.39 & sehat \\
\hline 15 & $\mathrm{~L}$ & 25 & 170 & 18 & 4.54 & 5.29 & sehat \\
\hline 16 & $\mathrm{P}$ & 40 & 155 & 17 & 3.93 & 3.95 & sehat \\
\hline 17 & $\mathrm{P}$ & 48 & 148 & 12 & 3.23 & 2.51 & sehat \\
\hline 18 & $\mathrm{P}$ & 39 & 175 & 16 & 3.4 & 3.78 & sehat \\
\hline 19 & $\mathrm{P}$ & 40 & 158 & 13 & 2.9 & 3.07 & sehat \\
\hline 20 & $\mathrm{~L}$ & 52 & 172 & 24 & 2.12 & 4.8 & tidak sehat \\
\hline
\end{tabular}

Pengujian keseluruhan system dilakukan pada 20 orang yang berbeda dimana untuk setiap orang dilakukan satu kali pengukuran. Dengan menganalisis hasil pengujian yang disajikan pada Tabel 3, maka diperoleh kinerja sistem sebagai berikut: Hasil pengukuran respirasi rate per menit pada 20 orang adalah $12-24$ bpm untuk anak-anak usia $8-11$ tahun, $15-25$ bpm Untuk remaja usia 17 - 22 tahun, dan 12 - 24 bpm untuk orang dewasa usia $39-52$ tahun, dengan tingkat keberhasilan rata-rata pada pengukuran respirasi adalah $95.70 \%$. Sedangkan hasil pengukuran kapasitas vital paru-paru adalah $3.87-4.13$ liter untuk anakanak (8 - 11 tahun), 2.2 - 4.54 liter untuk remaja (17 - 22 tahun) dan $2.12-3.93$ liter untuk orang dewasa (39 - 52 tahun) dengan tingkat keberhasilan rata-rata pada pengukuran kapasitas vital paru-paru adalah $97.67 \%$. Alat spirometer non-invasive ini dapat juga mendeteksi ada 4 orang yang terindikasi memiliki paru-paru tidak sehat. Dari pengujian keselurah sisitem ini maka dapat dinyatakan bahwa alat spirometer non-invasive yang dirancang dan direalisasikan ini telah bekerja dengan sangat baik. 


\section{KESIMPULAN}

Berdasarkan perancangan, realisasi dan hasil pengujian sistem yang telah dilakukan, maka penelitian ini dapat disimpulkan sebagai berikut:

1. Alat spirometer non-invasive dengan menggunakan sensor piezoelektrik telah berhasil dirancang dan direalisasikan untuk mendeteksi kesehatan paru-paru seseorang berdasarkan pengukuran nilai kapasitas vital paru-paru dan respirasi rate permenit, dengan tingkat persentase keberhasilan rata-rata pengukuran respirasi rate adalah sebesar $95.70 \%$ dan tingkat persentase keberhasilan rata-rata pengukuran kapasitas vital paru-paru adalah $97.67 \%$.

2. Pengguna alat spirometer non-invasive dapat memperoleh hasil pengukuran respirasi rate per menit dan kapasitas vital paru-paru sekaligus dapat juga informasi tentang hasil deteksi kondisi kesehatan paru-paru.

3. Dengan ditampilkannya hasil pengukuran sinyal respirasi dan hasil deteksi kondisi paruparu di LCD grafik serta data hasil pengukuran bisa disimpan di SD Card dan alatnya portabel, maka alat ini sangat mudah digunakan oleh siapapun dan dimanapun dengan nyaman.

\section{UCAPAN TERIMA KASIH}

Penulis mengucapkan terima kasih kepada instansi Kementrian Riset, Teknologi dan Pendidikan Tinggi Republik Indonesia yang telah mendanai penelitian ini melalui pemberian hibah penelitian produk terapan (Penelitian Hibah Bersaing).

\section{DAFTAR RUJUKAN}

Sini, J., Vikneswarim, A., Divya, J. (2015). Lung Volume Measurements: A Review Article. Asian journal of research in Biological and Pharmaceutical sciences 3(1): 47-51.

Fat'ak, M. (2010). Pengolahan Sinyal Respirasi dengan FIR Untuk Analisa Volume dan Kapasitas Pulmonary. Tugas Akhir. Surabaya. Politeknik Elektronika Negeri Surabaya.

Setiyo, A. (2010). Realisasi Sensor Piezoelektrik Untuk Pengukuran Respirasi Rate Berbasis $P C$. Tugas Akhir. Bandung. Institut Teknologi Telkom Bandung.

Aulia, R., Kemalasari., \& Ali, H. (2013). Analisa Kesehatan Paru-Paru Berdasarkan Pengukuran Volume dan Kapasitas Paru-Paru. Seminar Nasional SNPTE 2013. Prosiding (pp. 88-91).

Kemalasari., Ali, H. (2014). Analyze of Lung Condition Base on the Measurement of Respiration Rate and Vital Capacity of Lung Using Piezoelectric Sensor. International Conference on Biomedical Engineering Technology and Application. Proceeding ICBETA 2014 (pp. 138-142).

Kemalasari., Ratna, A., \& Paulus, W. (2016). Perencanaan dan Realisasi Alat Deteksi Infeksi Saluran Pernapasan Berdasarkan Pengukuran Kapasitas dan Volume Paru-Paru secara Non-Invasive Pasca Musibah. Seminar Nasional Teknologi Terapan (SNTT) 2016. Prosiding (pp .96-100). 
Fachrial, H., Endah, A. (2012). Uji Fungsi Paru. Journal CDK-192. 39(4): 305-307.

Planzer, R., Uyehara, J., McMullen, W.Pulmonary Function I \& II Lessons for use with the Biopac Student Lab, 42 Aero Camino, Santa Barbara-USA, Lesson 12 \& 13, 2000.

Faridah, M., Rizwan, A., \& Aniqa, M. (2011). Predicted and Recorded Vital Capacity in Students of Shalamar Medical and Dental College - Lahore. Pakistan Journal of Physiology. 7(2): 50-52. 